\title{
Professor KinNey on the Human Right to Health Care: Continuing the Conversation
}

\author{
R. GEORGE WRIGHT ${ }^{*}$
}

\section{INTRODUCTION}

For Professor Kinney, the idea of a human right to health care was a matter of central and continuing interest. ${ }^{1}$ Rather like a gemologist, Professor Kinney examined the facets ${ }^{2}$ of this right with discerning attention. This contribution continues the conversation with Professor Kinney at fundamental levels. ${ }^{3}$

Professor Kinney distinguished, in particular, a human right ${ }^{4}$ from a natural right; ${ }^{5}$ international human rights ${ }^{6}$ from other sorts of human rights; ${ }^{7}$ and a right

* Lawrence A. Jegen Professor of Law, Indiana University Robert H. McKinney School of Law. A more extensively documented version of this contribution can be found at the author's SSRN page.

1. See, e.g., Jason T. Eberl, Eleanor D. Kinney \& Matthew J. Williams, Foundation For a Natural Right to Health Care, 36 J. MED. \& PHIL. 537 (2011) [hereinafter Foundation]; Eleanor D. Kinney, Health Care Financing and Delivery in the US, Mexico and Canada: Finding and Establishing Intentional Principles For Sound Integration, 26 WIS. INT'L L.J. 934 (2009) [hereinafter Health Care Financing]; Eleanor D. Kinney, The International Human Right to Health: What Does This Mean For Our Nation and World?, 34 IND. L. REV. 1457 (2001) [hereinafter International]; Eleanor D. Kinney \& Brian Alexander Clark, Provisions For Health and Health Care in the Constitutions of The Countries of the World, 37 CORNELl INT'L L. J. 285 (2004) [hereinafter Provisions]; Eleanor D. Kinney, Realization of the International Human Right to Health Care in an Economically Integrated North America, 37 J. L. MED. \& ETHICs 807 (2009) [hereinafter Economically]; Eleanor D. Kinney, Realizing the International Human Right to Health For Non-Citizens in the United States, 1 Notre Dame J. InT'L Comp \& Hum. RTs. L. 94, 112 (2011) [hereinafter Non-Citizens] ("[r]ealizing the international human right to health must be achieved on a global level"); Eleanor D. Kinney, Realizing the International Human Right to Health: The Challenge of For-Profit Health Care, 113 W. VA. L. REV. 49 (2010) [hereinafter Challenge]; Eleanor D. Kinney, Recognition of the International Human Right to Health Care in the United States, 60 Rutgers L. REV. 335 (2008) [hereinafter United States].

2. Note the range of perspectives taken in the authorities cited supra note 1.

3. Thus, our attention is largely confined to the most foundational of Professor Kinney's concerns, with special attention to Foundation, supra note 1, and with some reference as well to International, supra note 1; Challenge, supra note 1; and United States, supra note 1.

4. For merely one instance of a focus on 'human' rights without corresponding reference to 'natural' rights, see International, supra note 1.

5. Much of the focus is explicitly on 'natural' rights, specifically in Foundation, supra note 1.

6. See, e.g., International, supra note 1; Economically, supra note 1.

7. In a sense, any familiar understanding of the idea of a human right implies its applicability beyond the borders of a single state, and thus international. Otherwise, the point of referring to a "human," as distinct from, say, a constitutional right within a legal system, would be unclear. Of course, one might refer to "international" human rights for other purposes, such as to 
to health care ${ }^{8}$ as distinct from a right to health itself. ${ }^{9}$ We briefly address these and other arguably even more fundamental issues herein.

First, though, we summarize Professor Kinney's explication of the idea of a human right to health. This summary draws upon several of Professor Kinney's published works, ${ }^{10}$ with primary attention to her jointly authored article entitled Foundation for a Natural Right to Health Care. ${ }^{11}$

In Foundation, Professor Kinney argues that "a fundamental human right to health exists in international law $^{12}$ and philosophical tradition, and governments are thus obligated to recognize this right through fair and just implementation."13 Officially adopted language has it that "[h]ealth is a fundamental human right indispensable for the exercise of other human rights," 14 and that "every human being is entitled to the enjoyment of the highest attainable standard of health conducive to living a life in dignity." ${ }^{15}$ Such language is, however, aspirational, ${ }^{16}$

emphasize questions of the right's embodiment in international treaties, or its fulfillment through international cooperation. For a mainstream use of the term, "international human rights," see JACK Donnelly \& Daniel J. Whelan, International Human Rights (5th ed. 2017).

8. See, e.g., Foundations, supra note 1; Economically, supra note 1; United States, supra note 1.

9. See International, supra note 1; Non-Citizens, supra note 1; Challenge, supra note 1. Professor Kinney recognizes a distinction between health care and health itself, as in, e.g., the very title of Provisions, supra note 1. One might distinguish between health care and health itself and regard both as a matter of human right, requiring different forms of recognition and compliance. Some writers have emphasized the differences between health care and health itself and would deny human right status to the latter. See, e.g., Joseph Raz, Human Rights in the Emerging World Order, 1 Transnat'L Legal TheOry 31, 45 (2010) (“'I]t would be silly to think that people really have a right to be healthy, a right which is violated every time they are not healthy."); Allen E. Buchanan, The Right to a Decent Minimum of Health Care, 13 PHIL. \& PuB. AfF. 55, 55 (1984) ("I think its implausibility is obvious.").

10. See in particular the sources cited supra note 3.

11. Foundation, supra note 1.

12. For some of the most directly relevant United Nations Declarations and Covenants, see G.A. Res. 217 (III) A, Universal Declaration of Human Rights (Dec. 10, 1948) (art. 25 in particular); International Covenant on Economic, Social and Cultural Rights, Dec. 16, 1993, 393 U.N.T.S. 3; Comm. on Econ., Soc. and Cultural Rights, General Comment No. 14: The Right to the Highest Attainable Standard of Health (Art. 12), U.N. Doc. E/C.12/2000/4 (Aug. 11, 2000). For useful summaries, see Eibe Riedel, The Human Right to Health: Conceptual Foundations, in Realizing the Right to Health 21 (Andrew Clapham et al. eds., 2009); Michael Krennerich, The Human Right to Health: Fundamentals of a Complex Right, in HealthCARE as a Human Rights (Sabine Klotz et al. eds., 2017).

13. Foundation, supra note 1, at 553.

14. Id. at 538-39.

15. Id. (quoting Comm. on Econ., Soc. and Cultural Rights, supra note 12, ๆ 1). See also Paul Hunt \& Gunilla Backman, Health Systems and the Highest Attainable Standard of Health, in Realizing the Right to Health, 40 (Andrew Clapham et al. eds., 2009).

16. Foundation, supra note 1, at 539. 
in the sense that no present society is thought to be in full compliance. ${ }^{17}$

Crucially, if a right to health or to health care is not universally recognized, or if there is disagreement as to the meaning of the right, it is important to be able to articulate the most basic and most persuasive justification of the right in question. ${ }^{18}$ Professor Kinney recognizes the diversity of possible basic justifications for health or health care rights. ${ }^{19}$ Apart from appeals to particular religious doctrines, Professor Kinney notes in particular the possibility of deontological $^{20}$ and even utilitarian ${ }^{21}$ attempts to justify human rights jurisprudence. $^{22}$

The focus of Professor Kinney and her colleagues is thus on the idea of a fundamental justification of a basic human right to health or to health care. One such possible justification is said by Professor Kinney to draw upon the natural law tradition, ${ }^{23}$ both historic ${ }^{24}$ and as revised by contemporary theories of basic human capabilities ${ }^{25}$ and self-realization. ${ }^{26}$

A natural law approach to justifying human rights claims to health or to health care should, at a minimum, properly account for the universality of the

17. $I d$.

18. See id.

19. Id. at 540 .

20. See Larry Alexander \& Michael Moore, Deontological Ethics, STAN. EnCYCloPEdia OF PHIL. (Oct. 17, 2016), https://plato.stanford.edu/entries/ethics-deontological [https://perma.cc/ 7UXC-KRMU].

21. See Julia Driver, The History of Utilitarianism, Stan. EnCyclopedia of Phil. (Sept. 22, 2014), https://plato.stanford.edu/entries/utilitarianism-history [https://perma.cc/6FKC-TTG2]. For a broader survey of influential schools of normative ethics, see SHELly Kagan, Normative Ethics 189-299 (1997); Marcia W. Baron, Philip Pettit \& Michael Slote, Three Methods OF ETHICs (1997) (adding aretaic or virtue-based normative ethics to the mix). If familiar forms of utilitarianism can justify universal human rights, so, one might ethical theories that treat the cultivation of familiar virtues as central. See Rown Cruft et Al., Philosophical Foundations of Human Rights (2015).

22. Foundation, supra note 1 , at 540.

23. Id. at 538 .

24. See id. at 543-47.

25. See id.; Martha C. Nussbaum, Creating Capabilities: The human development APPROACH (2013); AMARTYA SEN, The IDEA OF Justice ch. 2 (2011); Efrat Ram-Tiktin, The Right to Health Care as a Right to Basic Human Functional Capabilities, 15 ETHICAL THEORY \& Soc. PRAC. 337 (2012).

26. See id. For discussions of self-realization, self-actualization, or self-fulfillment in broader ethical and political contexts, see, e.g., John StUART Mill, On LiberTy (Gertrude Himmelfarb ed. 1975) (1859); T.H. Green, Prolegomena to Ethics (1883). See also, David O. Brink, Perfectionism and the Common Good: Themes in the Philosophy of T.H. Green (2003); Thomas Hurka, Perfectionism (1993); Steven Wall, Perfectionism in Moral and Political Philosophy, STAN. ENCYCLOPEDIA OF PHIL., https://plato.stanford.edu/entries/perfectionism-moral [https://perma.cc/4BJ7-R63G] (last updated Dec.15, 2017). 
right, across cultures and degrees of economic, scientific, and technological development. ${ }^{27}$ But that natural law justification should also recognize the ways in which the right must have a variable and pluralistic dimension, in properly accommodating differences among cultures and their degrees of economic, scientific, technical development. ${ }^{28}$

For some purposes, settling upon some specific deep justification for a human right to health care may not much matter. ${ }^{29}$ But any putative human right, certainly including health care, will quickly become controversial along many substantive fronts. ${ }^{30}$ Some $^{31}$ form of a fundamental justification aspiring to objectivity $^{32}$ and universality ${ }^{33}$ then becomes indispensable.

A right to health care, whether objectively morally grounded or not, is said to be fundamental in that it is "indispensable for the exercise of other human rights." ${ }^{34}$ More broadly, a natural law theorist in particular might defend a right to some level of health care as conducive not necessarily to the best balance of pleasure over pain, ${ }^{35}$ but to promoting the good of person and the transcending common good. ${ }^{36}$ Historically, pursuit of a presumed common good has been central to the natural law tradition, as in Thomas Aquinas. ${ }^{37}$ For Aquinas, bodily

27. See Foundation, supra note 1, at 543.

28. See id.; International, supra note 1, at 1467.

29. See Foundation, supra note 1, at 542 (referring to Mary Ann Glendon's discussion of Jacques Maritain's report of the diversity of motivating principles underlying international endorsement of some basic human rights). See also Mary Ann Glendon \& Seth D. Kaplan, Renewing Human Rights, First Things (Feb. 2019).

30. See Foundation, supra note 1, at 538-39.

31. Id. at 540 (listing deontological, utilitarian, and natural law approaches to justifying human rights claims and responsibilities).

32. See id. at 548. See generally Lorrain Daston \& Peter Galison, Objectivity (2007) (for an account of recent understandings of the idea of objectivity in and beyond the moral realm); Calder v. Bull, 3 U.S. 386 (1798) (Iredell, J., dissenting) (For skepticism of the natural law in the United States jurisprudential context); Oliver Wendell Holmes, Jr., Natural Law, 32 HARV. L. REV. 40 (1918).

33. See generally Immanuel Kant, Groundwork of the Metaphysics of Morals (Mary Gregor \& Jens Timmermann eds., 2d ed. 2012) (1785).

34. Foundation, supra note 1, at 538. By loose analogy, consider the constitutional status of the right to vote in state elections as preservative of other important rights. See, e.g., Harper v. Virginia State Bd. of Elections, 383 U.S. 663, 667 (1966) (quoting Reynolds v. Sims, 377 U.S. 533, 561-62 (1964); Yick Wo v. Hopkins, 118 U.S. 356, 370 (1886).

35. As in some crude versions of utilitarianism. See Jeremy Betham, The Principles of Morals and Legislation (Prometheus 1988) (1781).

36. See Foundation, supra note 1, at 542 (citing the modern natural law theorist Jacques Maritain). See also John Finnis, Natural Law and Natural Rights 125-54 (Paul Craig ed., 2d ed. 2011).

37. See, e.g., Thomas Aquinas, Summa Theologica, part I-II, question 90, art. 2, respondio (Kevin Knight ed. 2017) available at www.newadvent.org/summa/2090.htm [https://perma.cc/6SHA-Q7KE] ("the law is chiefly ordained to the common good") (linking the 

TO HEALTH CARE

integrity and bodily health are among the most fundamental of all goods. ${ }^{38}$

How the crucial good of bodily ${ }^{39}$ health is to be promoted, pursuant to Thomistic natural law, is then open to a range of interpretations. Aquinas may be best interpreted as neither incapable of following the logic justifying economic markets, nor incapable of profound critique of markets. ${ }^{40}$ One striking result is Aquinas's conclusion that in some cases, desperate needs to sustain minimal bodily well-being cannot so much override, but fundamentally transform, the basic laws of individual property. ${ }^{41}$ Neither the classical tradition ${ }^{42}$ nor Professor

exercise of reason, the common good, and promoting ultimate happiness or well-being). From among a vast critical and expository literature, see, e.g., JoHn FinNIS, AQUINAS: MorAL, Political, And Legal Theory (1998); The Ethics of Aquinas (Stephen J. Pope ed. 2002). For a more modern but related argument, see Daniel M. Hausman, A Lockean Argument for Universal Access to Health Care, 28 Soc. PHIL. \& PoL'y 166, 166 (2011).

38. See Aquinas, supra note 37, part I-II, question 94, art. 2, respondio (on the most basic goods to be sought pursuant to the natural law).

39. Aquinas is, of course, concerned here not only with bodily health and integrity, but with psychological health, and with health of character. See AQUINAS, supra note 37, part I-II, questions 55-66. See also John Budziszewski, Commentary on Thomas Aquinas's Virtue Ethics (2017).

40. For an exceptionally worthy discussion of Aquinas's appreciation for and fundamental critique of market operations and outcomes, see generally MARY L. HIRSCHFIELD, AQUINAS AND the MARKet: Toward A Humane ECONOMy (2018). See also, for more contemporary perspectives, first CHARLES E. LindBlom, The MARKet System: What IT Is, How IT Works, AND What to MaKe of It (2001), and then, conflictingly, Jason Brennan, Why Not CAPitAlism? (2014); G.A. Cohen, Why Not Socialism? (2009); Friedrick A. HAyeK, The RoAd to Serfdom (1945); JOHN For a classic instance of what is often mistakenly thought of as an optional private redistribution of resources, see St. Cardinal Bonaventure, The Soul's Journey into God, The Tree of Life, and the Life of St. Francis 254 (Paulist Press ed., Ewart Cousins trans.) (1978) (1263).E. Roemer, A Future For Socialism?(1994); Ludwig Von Mises, Socialism: AN ECONOMic And Sociological AnALysis (J. Kahane tras.1962); Friedrick A. Hayek, The Use of Knowledge in Society, 35 Am. Econ. REv. 519 (1945); Oscar Lange, On the Economic Theory of Socialism: Part One, 4 ReV. ECON. Stud. 53 (1936); Oscar Lange, On the Economic Theory of Socialism: Part Two, 4 Rev. ECon. Stud. 123 (1937); Abba P. Lerner, Economic Theory and Socialist Economy, 2 REV. ECON. STUD., 51 (1934). For a brief but even-handed account of the "socialist calculation" debate, see Allen BuCHANAN, ETHICS, EFFICIENCY, AND THE MARKET 10917 (1988).

41. See Aquinas, supra note 37, part II-II, question 66, art. 7, respondio. See also John Chrysostom, Discourse II, in On Wealth and Poverty 3 (St. Vladimir's Seminary Press 1999) $(\sim 390)$. Professor Kinney and her colleagues cite Aquinas's discussion of surplus private property as genuinely owned by a person with no alternative to meeting their immediate desperate need, Foundation, supra note 1, at 547.

42. For a classic instance of what is often mistakenly thought of as an optional private redistribution of resources, see St. Cardinal Bonaventure, The Soul's Journey into God, The Tree of Life, and the Life of St. Francis 254 (Paulist Press ed., Ewart Cousins trans.) 
Kinney herself assumes, however, that crucial bodily health needs must be met in all instances by some form of direct governmental provision. ${ }^{43}$

The traditional natural law concepts of the common good, human flourishing, and the fullest development of human capacities have recently been taken up in the 'capabilities' approach of writers such as Martha Nussbaum. ${ }^{44}$ Professor Kinney interprets the capabilities approach to individual flourishing ${ }^{45}$ and the common good $^{46}$ as implying certain basic rights and corresponding obligations. ${ }^{47}$ Among the most fundamental elements of flourishing is, as Professor Nussbaum argues, ${ }^{48}$ bodily health. ${ }^{49}$ This fundamental capability then implies certain associated rights.

Ultimately, Professor Kinney and her colleagues again recognize an international near consensus "that a fundamental human right to health exists in international law and international law and philosophical tradition, and governments are thus obligated to realize this right through fair and just implementation." ${ }^{50}$

This defense of a human right to health care, however, is hardly universally accepted. Consider in particular the broad critique of human rights theory and practice of Professor Eric A. Posner. ${ }^{51}$ Posner argues that:

[T] he proposition that all people enjoy a specified set of human rights . . . is highly controversial among philosophers. The absence of an agreed upon philosophical justification for human rights yields well-known

(1978) (1263).

43. See Challenge, supra note 1, at 59, 64-5. See also Foundation at 553 (ultimately, "a fundamental human right to health exists in international law and philosophical tradition, and governments are thus obligated to realize this right through fair and just implementation," but "the realization of human rights, even the provision of benefits to individuals, does not necessarily require that government do the providing."). The nature, efficacy, and meaning of health care in the thirteenth century are in some, but certainly not all, respects different in contemporary health care systems. See, e.g., Paul Starr, The Social Transformation of American Medicine 3-28 (2017 ed.).

44. See, e.g., Martha Nussbaum, Creating Capabilities: The Human Development APproACH ch. 2 (2013) [hereinafter Creating Capabilities]; Martha Nussbaum, Capabilities and Human Rights, 66 FordHAM L. REV. 273, 287 (1997) (referring to "bodily health" as "being able to have good health, including reproductive health; to be adequately nourished; to have adequate shelter"). See also Ram-Tiktin, supra note 25.

45. Foundation, supra note 1 , at 550.

46. Id.

47. Id.

48. See sources cited supra note 44 .

49. Creating Capabilities, supra note 44 , at 33.

50. Foundation, supra note 1, at 553.

51. See generally Eric A. Posner, Human Welfare, Not Human Rights, 108 Colum. L. Rev. 1758 (2008) [hereinafter Human Welfare]; ERIC A. Posner, The Twilight of Human Rights LAW (2014). 

TO HEALTH CARE

practical difficulties: States disagree about which rights are human rights, about which human rights should have priority, about how resources should be allocated for the purpose of correcting human rights violations, and about how much respect should be given to cultural variation. ${ }^{52}$

Below, we continue the conversation with Professor Kinney as to these and other points.

\section{THE DiSTINCTIVE FoundATIONS OF HUMAN RIGHTS CLAIMS IN GENERAL}

Professor Kinney understandably seeks to justify claims of a human right to health care as securely as possible. Her preference, as we have seen, ${ }^{53}$ is for an updated natural law-based approach. Natural law theories of any sort are at present not generally favored, even among loosely sympathetic writers. ${ }^{54}$ Almost every conceivable approach to justifying human rights claims is endorsed somewhere in the relevant literature. ${ }^{55}$ But it seems doubtful that any metaphysically less ambitious approach to justifying human rights claims can, over time, supply the motivation for substantial self-sacrifice for the sake of remote strangers. ${ }^{56}$

Professor James Griffin in particular has argued that the underlying logic and justification of human rights claims historically drew crucially upon theology, ${ }^{57}$ with a familiar later transition toward secularity. ${ }^{58}$ But "[w]hen during the seventeenth and eighteenth centuries the theological content of the idea [of

52. Human Welfare, supra note 51, at 1760 (footnote omitted).

53. See supra Section I.

54. See, e.g., Vittorio Bufacchi, Theoretical Foundations for Human Rights, 66 PoL. STUD. 601 (2017) (avoiding a natural law approach in favor of a 'deflationary' theory relying on social construction and convention).

55. For leading contemporary contributions, see generally Charles R. BeITz, THE IDEA of Human Rights (2009); Jack Donnelly, Universal Human Rights in Theory and Practice (2013); James Griffin, On Human Rights (2008); Rhoda E. Howard-Hassmann, In Defense of Universal Human Rights (2018); Human Rights Futures (Stephen Hopgood et al. eds., 2017); Samuel Moyn, Not Enough: Human Rights in an Unequal World (Harvard Univ. Press 2018); James Nickel, Making Sense of Human Rights (2d ed. 2007); Michael J. Perry, Toward A Theory of Human Rights: Religion, Law, Courts (2007); Philosophical Foundations of Human Rights (Rowan Cruft et al. eds., 2015); Henry Shue, Basic Rights: Subsistence, Affluence, and U.S. Foreign Policy (2d ed. 1996); Carl Wellman, The Moral Dimensions of Human Rights (2010); Bufacchi, supra note 54; Joseph Raz, Human Rights Without Foundations (Oxford Legal Stud., Research Paper No. 14/2007, 2007), https://ssrn.com/abstract=999874 [https://perma.cc/A2XL-243L].

56. For a brief discussion, see GRIFFIN, supra note 55, at 1-2; see also infra note 123 and accompanying text.

57. See GRIFFIN, supra note 55, at 1 .

58. See id. at 1-2. 
human rights] was abandoned, nothing was put in its place." ${ }^{, 59}$

Over the past century or so, the historic theological realism and then the succeeding secular realism once thought to validate human rights claims has increasingly been abandoned in favor of a variety of less ambitious approaches to justifying human rights, if not to disposing of the project of justification. Ultimately, the meaning, weight, and bindingness of claims as to human rights depend upon the metaethics underlying those claims. The less ambitious the metaethical grounding, the less binding the substantive human rights claim is likely to be. ${ }^{.0}$

Thus, historic forms of moral realism have given way to a continually splintering variety of less ambitious ${ }^{61}$ metaethical approaches. Among the current rubrics would be anti-realism, constructivism, some forms of contextualism, conventionalism, some forms of deflationism, emotivism, reductive and eliminative materialism, metaethical minimalism, non-cognitivism, pragmatism, projectivism, quasi-realism, ${ }^{62}$ and moral skepticism, Pyrrhonian ${ }^{63}$ or otherwise ${ }^{64}$

Contemporary advocates of these variously diluted metaethical views do not invariably abandon the use of terms such as 'inviolable,' 'inviolability,' or the 'sacred,' that one might well associate with a more ambitious metaethics. ${ }^{65}$ Whether any attenuated metaethics can fully cash the checks written by terms such as 'inviolability' is doubtful. But the long-term observance of progressive human rights norms may ultimately depend on just such matters.

The less ambitious approaches to the metaphysics of human rights do have a long history. Merely for example, consider the classic atoms-and-the-void

59. Id. at 2 .

60. But see the implicit argument to the contrary in the arguably misleadingly titled article by Ronald Dworkin, Objectivity and Truth: You'd Better Believe It, 25 PHIL. \& PuB. AfF. 87 (1996) (the net value of Professor Dworkin's references to 'objectivity' is limited). See, e.g., Robert D. Sloane, Human Rights for Hedgehogs?: Global Value Pluralism, International Law, and Some Reservations of the Fox, 90 B.U. L. REV. 975, 989 (2010).

61. Or if technically not less realist, then self-stultifying as justifications for human rights claims. See generally, e.g., John Mackie, Ethics: Inventing Right And Wrong (1977) (the "error theory," as well as the non-cognitivist approach).

62. Many of these categories overlap. See generally, e.g., SimOn Blackburn, Essays In QUASI-REALISM (1993) (projectivism and quasi-realism).

63. See generally, e.g., Pyrrhonian SkePticism (Walter Sinnott-Armstrong ed. 2004).

64. Nearly all of these rubrics are addressed in the online Stanford Encyclopedia of Philosophy. Stanford Encyclopedia of Philosophy, https://plato.stanford.edu/ [https://perma.cc/ W58E-JXBH]. For more a comprehensive treatment of metaethics, see generally, e.g., ANDREW Fischer, Metaethics: An Introduction (2014); Simon Kirchin, Met Aethics (2012); ANdrew Miller, Contemporary Metaethics: An Introduction (2013); Mark van Roojen, METAETHICS: A CONTEMPORARY INTRODUCTION (2015). On constructivism and conventionalism in human rights theory, see generally Bufacchi, supra, note 54.

65. See generally, the relevant writings of Dworkin, supra note 60; RONALD DwORKIN, RELIGION Without God (2013). 

TO HEALTH CARE

metaphysics of the poet Lucretius. ${ }^{66}$ Lucretius famously adopts a rigorous materialism of mind, arguing that the building blocks of all things in nature are called, "according to our needs, matter, atoms, generative bodies, elements and seeds, and first-beginnings, since it is from these that all proceeds." ${ }^{67}$ More simply, "the universe's nature consists, in essence, of two different things: for there is matter, and there is void, in which the particles of matter move hither and thither." ${ }^{68}$ The mind itself is said by Lucretius to consist entirely of matter, in the form of minute particles. ${ }^{69}$

The problem is that thinking of the mind as consisting of minute particles, even at the quantum level, does not seem to leave much room for classic freedom of the will, ${ }^{70}$ for classical moral responsibility, ${ }^{71}$ or for a genuinely binding morality of any familiar human rights. ${ }^{72}$

Hence the current dilemma for advocates, including Professor Kinney, of any sort of natural law-oriented basis for human rights claims, including a human right to health care. Contemporary culture tends to view natural law theories of any political valence as unpersuasive, incredible, or realistically unavailable. ${ }^{73}$ But many of these same critiques of even the most appealing versions of natural law theory can be readily applied as well to any approach to metaethics that could

66. See Lucretius, The Nature of Things (Alicia Stallings trans., Penguin Classics ed., 2007) ( 50 BCE).

67. Id. at 4-5. This thoroughgoing materialism does not, however, prevent Lucretius from then almost immediately invoking ideas such as impiety, sin, wickedness, wrongfulness, and defilement. These terms are broadly inconsistent with pure materialism, at least as these ideas are normally understood. See DwORKIN, supra note 65.

68. LUCRETIUS, supra note 66, at 5 ("[a]nd specifically, "material makes up the composition of the mind"”). $I d$. at 77 (in particular, the mind consists of minute "particles").

69. Id.

70. See e.g., Anthony R. Cashmore, The Lucretian Swerve: The Biological Basis of Human Behavior and the Criminal Justice System, ProceEdingS of THE NAT'L ACAD. Of SCI. U.S.A. (Jan. 12, 2010), www.pnas.org/cgi/doi/10.1073/pnas.0915161107 [https://perma.cc/72CZ-9LUK]. The "Lucretian Swerve" is drawn from Lucretius, LuCRETIUS, supra note 66, at 77.

71. See Bruce N. Waller, Against Moral Responsibility ch. 2 (2011).

72. See, e.g., Richard Garner, Beyond Morality (Temple Univ. Press, 1994); The End of Morality: Taking Moral Abolitionism Seriously (Richard Garner \& Richard Joyce eds., 2019); Richard Joyce, The Myth of Morality (2007); Alex Rosenberg, The Atheist's Guide to Reality: Enjoying Life Without Illusions (2011). See generally R. George Wright, Criminal Law and Sentencing: What Goes With Free Will?, 5 DreXel L. REV. 1 (2012). There is a tendency at present to believe that if all versions of morality were universally, consistently, and deeply rejected, life would be either largely unaffected or else more humane.

73. See MACKIE, supra note 61 (providing a classic statement). See also the authorities cited supra note 73 . It is certainly possible that a thoroughly de-moralized society could make some provision for the health care of persons, perhaps based on reciprocal altruism, where such a policy promoted the evolutionary adaptive fitness of health care donors. See generally Robert L. Trivers, The Evolution Reciprocal Altruism, 46 Q. REV. Biol. 35 (1971). 
vindicate, in any meaningful way, human rights in general, or a human right to health care in particular.

\section{THE HuMAN Right TO HEALTH CARE AND THE CONFLICTING UNDERSTANDINGS OF FAIR EQUALITY}

At a more practical level, but still of fundamental importance, is the question of the concrete meaning of fairness and equality in the distribution of health care. As it turns out, the alternative approaches to fairness and equality in health care rights parallel those that seek to concretely interpret the general idea of equality itself. Unfortunately, in neither the context of health care access nor in that of the idea of equality itself have the leading contemporary scholars reached anything remotely like a consensus. ${ }^{74}$

With some oversimplification, understandings of fairness and equality in the context of health care rights fall into five largely distinct families. In roughly descending order of stringency, these five families may be thought of as follows: First are the approaches to health care rights that we may think of as especially rigorous and demanding with respect to genuine equality of distribution. ${ }^{75}$ Second are the approaches that we may refer to as "prioritarian." "Th Third is the family of approaches referred to as "sufficientarian" in character. ${ }^{77}$ Fourth, there is the family of approaches that ranges, within the category itself, from something like "decency" $"$ in provision, to some forms of mere minimalist provision, ${ }^{79}$ as in a minimalist focus on public health matters such as sanitation and vaccinations against contagious diseases. Fifth, and finally, there is the category of what we might call mere formalism in the provision of health care. ${ }^{80}$

These five contending schools of thought regarding the meaning of fairness and equality in health care rights track their counterparts in the broader debates over equality more generally. Writers such as G.A. Cohen ${ }^{81}$ and Philippe van Parijs $^{82}$ are sometimes thought of, for example, as relatively stringent egalitarians.

74. See R. George Wright, Equal Protection and the Idea of Equality, 34 L. \& INEQ. 1 (2016). Linking the idea of equality with avoiding (improper) discrimination, however, carries us only so far. See George J. Annas \& Wendy K. Mariner, (Public) Health and Human Rights in Practice, 41 J. HeAlth Pol., Pol'y \& L. 129, 136 (2016).

75. See infra notes $81-83$ and accompanying text.

76. See infra notes $84-86$ and accompanying text.

77. See infra notes 87-88 and accompanying text.

78. See infra notes 89-92 and accompanying text.

79. See id.

80. See infra note 93 and accompanying text.

81. See, e.g., G.A. Cohen, Rescuing Justice And EQuAlity (2008) (a generally left-critique of Rawlsianism). See also Dani Filc, The Liberal Grounding of the Right to Health Care: An Egalitarian Critique, 112 THEORIA 51 (2007).

82. See, e.g., Philippe van Pariss, Real Freedom For All: What (If Anything) Can JUSTIFY CAPITALISM? (1995). Any health care system that bars supplemental payments or payments outside that system has the potential for a meaningful equalization of the available medical care, 

TO HEALTH CARE

A desire for as strict an egalitarianism as is feasible tells us little, however, about how to address, at the same time, arguable inequalities among young and old, the healthy and the terminally ill, gender differences, justice and equality between generations, and the health care needs of those persons severely disabled from birth whose circumstances can be improved to widely varying degrees. ${ }^{83}$

Prioritarianism, in contrast, does not invariably endorse every possible move in the direction of greater equality. ${ }^{84}$ Prioritarians point out that it is possible to increase equality in some respect mainly at a disproportionate cost to persons who are themselves not especially well off, in some supposedly absolute and noncomparative sense. ${ }^{85}$ Prioritarians thus give some unspecified degree of preference to the less well off, while avoiding unduly rigid forms of egalitarianism as well as any forms of utilitarianism. ${ }^{86}$

Sufficientarianism, in contrast, holds in the health care context that what is morally crucial about distributions is not precisely the contrast between equality and any degrees of inequality, but between having enough - a genuine sufficiency - and having too little - an insufficiency. ${ }^{87}$ One problem for sufficientarians, however, concerns how to approach a hypothetical problem in which an inevitable part of the cost of moving some health care recipients from barely below sufficiency to barely at sufficiency is the worsening, to one degree

at least in some respects. Of course, these restrictions themselves would not begin to address inequalities of various sorts as between young and old, or between persons who are variously severely disabled versus those who are not. For background, see, e.g., NORMAN DANIELS, JusT Health: Meeting Needs Fairly (1St ed. 2007); Tom L. Beauchamp \& James J. Childress, Principles of Biomedical Ethics (7th ed. 2012); Robert M. Veatch, Justice and the Right to Health Care: An Egalitarian Account (T.J. Boll \& W.B. Bondeson eds., 1991).

83. See Cohen, supra note 81. See also R. George Wright, Can Health Care Law and Policy Be Guided by Basic Values?: The Crucial Role of Perfectionist Solidarity, 86 U. CIN. L. REV. 971 (2018).

84. See generally Derek Parfit, Equality and Priority, 10 RATIO 202 (1997); Derek Parfit, Another Defense of the Priority View, 24 Utilitas 399 (2012); Richard Norman, Equality, Priority and Social Justice, 12 RAtio 178 (1999); Michael Weber, Prioritarianism, 9 PHiL. Compass 756 (2014).

85. The claim that the "absolute" aspects of someone's circumstances can be disentangled from the relative or comparative aspects of their circumstances may not be merely mistaken, but importantly mistaken, especially if values such as community, solidarity, and fraternity are taken seriously. See Fred Hirsch, Social Limits to Growth 27 (Routledge 2nd ed.1978) (on "positional" goods and services).

86. See sources cited supra note 84 .

87. Among today's leading sufficientarians are Harry Frankfurt and George Sher. See, e.g., HARry G. Frankfurt, ON INEQUALITy (2015); Harry Frankfurt, Equality as a Moral Ideal, 98 Ethics 21 (1987); George Sher, Equality For Inegalit arians (2014). Sufficientarians also tend to rely on a distinction between someone's comparative position, relative to others, and the goodness or badness of one's circumstances in some absolute sense. See also Ram-Tiktin, supra note 25 . 
or another, of the health care rights of some even worse-off persons. ${ }^{88}$

Closely akin to sufficientarianism is an approach that emphasizes something like a decent minimum ${ }^{89}$ of realistic access to health care. This approach, like prioritarianism and sufficientarianism, inevitably suffers from a certain vagueness..$^{90}$ The primary concern here, though, is whether a decent minimalism, especially if construed as requiring less than genuine sufficiency, meets even the current international law requirements regarding health care rights. ${ }^{91}$ After all, those requirements have sometimes been ambitiously summarized in terms of aspiring to the "highest attainable"

Finally, a right to health care might be treated in largely formalist terms, with proper accounting for the positive and negative externalities associated with one's health, including the effects of one's own health on the health of non-consenting third parties. ${ }^{93}$ Whatever their merits, such approaches amount less to interpretations of a substantive human right to health care than to a denial of such a right.

88. Such a move, however otherwise morally unattractive, would decrease the number of persons below sufficiency, while moving no one from the category of sufficient health care to insufficient health care. See SHLOMi Segall, Why IneQuality Matters: LuCK EGALITARIANiSM, Its MEANing AND VALue (2016) (discussing several approaches).

89. See, e.g., Stephen Nathanson, Equality, Sufficiency, Decency: Three Criteria of Economic Justice, 30 J. PHIL. RES. 367 (2005); see, e.g., Allen E. Buchanan, The Right to a Decent Minimum of Health Care, 13 PHiL. \& PuB. AfF. 55 (1984) (discussing access specifically in the health and healthcare context); Gary E. Jones, The Right to Health Care and the State, 33 PHIL. Q. 279, 279 (1938) (citing Charles Fried, Equality and Rights to Health Care, 6 Hastings CTR. ReP. 29 (1976)).

90. In many contexts, vague categories are neither refinable nor dispensable. See generally Timothy Williamson, VAgueness ch. 1 (1994).

91. While the right to health is not to be understood as a right to be healthy, the right in question has been formulated as "the right to the highest attainable standard of health." See Comm. on Econ., Soc. \& Cultural Rights, General Comment No. 14: Right to the Highest Attainable Standard of Health (Art. 12), U.N. Doc. E/C.12/2000/4 (Aug. 11, 2000) (discussing Article 12 of the International Covenant on Economic, Social and Cultural Rights) (emphasis in the original). See also International, supra note 1, at 1470 (providing Kinney's thoughts on General Comment 14).

92. See, International, supra note 1, at 1470. Whether this stringent interpretation is persuasive is considered by, see, e.g., BUCHANAN, supra note 89, at 56; Raz, supra note 9, at 45 (we should reject the highest attainable standard test if taken to refer to what is factually attainable); Jonathan Wolff, The Demands of the Human Right to Health, 86 Proc. Aristotelian Soc'y 217, 222 (2012) (citing Onora O'Neill, The Dark Side of Human Rights, 81 InT'L AfF. 427 (2005)). While all rights require some ranking and prioritization as among themselves, a right to health care may require, or presuppose, fulfillment of a broad range of partly competing economic and social rights.

93. For a sophisticated libertarianism, see, e.g., Robert NozICK, ANARCHy, StATE \& UTOPIA (1974). For skepticism as to demanding forms of a right to health care, see, e.g., Richard D. Lamm, The Case Against Making Healthcare a "Right," 25 Hum. RTs. 8 (1998). 

TO HEALTH CARE

One important problem attending fair equality in general and health care rights in particular, whatever the interpretation, has to do with problems of free, responsible, voluntary risky choices and bad outcomes. These problems are addressed in what is called "luck egalitarianism." While luck egalitarian concerns apply to a wide range of contexts, they apply with particular force to the logic of health care rights. Meaningfully pursuing any implications of luck egalitarianism herein would be impossible. ${ }^{95}$ But to continue the conversation in which Professor Kinney engages, we need only point to some basic unresolved problems.

Very roughly, a simple form of luck egalitarianism would notice that some bad health outcomes seem to have nothing to do with any responsible choices on the part of the person suffering the bad, and perhaps expensive, health condition. Being born with a serious and continuing physical disability could fall into this category. On the other hand, many people would distinguish such cases from those in which the bad health outcome seems to result from a different kind of luck, in which the adversely affected party seems to have deliberately, knowingly, understandingly, voluntarily, freely, and responsibly assumed the risk of precisely the kind and severity of the bad health outcome that happened to result.

Which activities, if any, fall into the latter category remains controversial. Perhaps we might think of an undistracted veteran professional skier who falls and breaks a leg on a well-tended ski run. But how should we classify cases of familiar sorts of occupational diseases, or addictive cigarette smoking? Many choices are constrained and conditioned by one's social and economic circumstances. Even one's apparent capacity for effort and initiative may reflect the first or non-responsible sort of luck.

A further complication is that some risky behaviors may result in not only foreseeable kinds and degrees of harms to health, but in much more severe and more expensive health harms than the actor could reasonably have foreseen. A luck egalitarian approach to such injuries might or might not subsidize the treatment of all of the harm in such cases, or at least treatment for the harm attributable to unforeseeable consequences of the actor's choices. And more broadly, luck egalitarianism must at some point confront issues of moral hazard ${ }^{96}$

94. The idea of luck egalitarianism was initially associated with its evolving use by Professor Ronald Dworkin. See, e.g., Ronald Dworkin, Equality, Luck and Hierarchy, 31 PHIL. \& PUB. AfF. 190 (2003). For comprehensive accounts, see SEGALL, supra note 88; Richard Arneson, Rethinking Luck Egalitarianism and Unacceptable Inequalities, 40 PHIL. TopICs 153 (2012); Nicholas Barry, Reassessing Luck Egalitarianism, 70 J. Pol. 136 (2008); Marc Fleurbay, Freedom With Forgiveness, 4 Pol., PHIL. \& Econ. 29 (2005); Kok-Chor Tan, A Defense of Luck Egalitarianism, 105 J. PHIL. 665 (2008); Peter Vallentyne, Brute Luck, Option Luck and Equality of Initial Opportunities, 112 Eтнісs 529 (2002). For a concise overview, see Kasper Lippert-Rasmussen, Justice and Bad Luck, StAn. EnCYClOPEDIA OF PHIL. (2005), https://plato.stanford.edu/ entries/justice-bad-luck [https://perma.cc/8U6A-ZGWD].

95. For a useful start, see sources cited supra note 94.

96. See, e.g., Amy Finkelstein, Moral Hazard in Health Insurance (2014). 
and of the logic of mercy and solidarity underlying opportunities for bankruptcy. ${ }^{97}$

Each of these concerns requires continuing conversation among proponents and critics of any form of a human right to health care. But there are also unresolved questions regarding the crucial dependencies of health, and health care, on a wide range of other rights and statuses, as well as of the international redistribution of resources that may be required by a human right to health care. We briefly continue the conversation on these themes below.

\section{THE HuMAN Right to HEALTH CARE: INTERDEPENDENCIES WITH OTHER RIGHTS AND STATUSES AND THE QUESTION OF INTERNATIONAL RESOURCE REDISTRIBUTION}

Among the continuing conversational threads is the relations between health and the social and economic determinants of health, quite apart from health care and medical treatments. It has been suggested that public health, and certainly individual health, is less a function of what we normally classify as health care than of what we might call the social and economic determinants of health. Health care by itself obviously does not even approach ensuring one's health. ${ }^{98}$ Nor is one's health invariably dependent upon one's personal health care. ${ }^{99}$

Health tends, plainly, to reflect social advantages and disadvantages along several axes, including economic class, education, place of residence, race, and gender. ${ }^{100}$ Some of these social determinants seem to combine the operations of luck $^{101}$ with prevailing patterns of broader dominance and subordination. ${ }^{102}$

97. See, e.g., Shlomi Segall, In Solidarity with the Imprudent: A Defense of Luck Egalitarianism, 33 Social Theory \& PraC. 177 (2007).

98. See, e.g., Kimberley Brownlee, Do We Have a Human Right to the Political Determinants of Health?, in Philosophical Dimensions of Human Rights ch. 28 (Rowan Cruft et al. eds., 2015); D. Robert MacDougall \& Griffin Trotter, Rights and Basic Health Care, 36 J. MED. \& PHIL. 529, 531 (2011); Barbara Wilson, Social Determinants of Health from a Rights-Based Approach, in Realizing the Right to Health, 60 (Andrew Clapham et al. eds., 2009).

99. See sources cited supra note 98. Thus, the familiar adverse selection effect of many healthy young adults declining to buy health insurance, given their priorities, thereby raising insurance premiums for others, and perhaps impairing the viability of the health insurance scheme in question. See, e.g., Timothy J. Layton, Randall P. Ellis \& Thomas G. McGuire, Measuring Efficiency of Health Plan Payment Systems in Managed Competition Health Insurance Markets (Nat'l Bureau of Econ. Research, Working Paper No. 21531, 2015), https://www.nber.org/ papers/w21531.pdf.

100. See, e.g., Kathryn Strother Ratcliff, The Social Determinants of Health: LOOKING UpSTREAm (2017); Donald BARR, HeAlth DisParities IN THE United States: Social Class, Race Ethnicity \& Health, (2nd ed. 2014). See also Norman Daniels, Just Health (2008) (elaborate treatment of health in the context of inequalities of opportunity).

101. See supra notes $94-97$ and accompanying text.

102. See, e.g., the authorities cited supra note 100; Jayna Fishman \& Douglas Mackay, Rawlsian Justice and the Social Determinants of Health, 36 J. APPLIED PHIL. 608 (2018). 
It is not simply that health, or the lack thereof, affects and is crucially affected by the other rights and opportunities. Actually, "if other factors matter more to health than health care, it is not at all evident that it is health care and not those other determinants [of health] that should be redistributed." ${ }^{03}$ Perhaps societies that value health are best advised not to focus, primarily, on health care itself, but on the crucial social and economic sources of illness, disease, and poor health. ${ }^{104}$ Or put in terms of rights, a right to health care is perhaps best not merely supplemented by, but subordinated to, a right to fair social and economic opportunity in other basic respects. ${ }^{105}$ Dramatically put, it has thus been argued that "society does more to move its citizens toward their fair share of health when it devotes the equivalent of the health care budget to improving the social determinants of health than when it runs a national health care system." ${ }^{\text {106 }}$ Or more dramatically yet, insofar as the focus is on fair opportunity in advanced societies, "an equal opportunity account requires that society spend none of its health budget on health care and all of it on ameliorating the social determinants [of ill health] instead." 107

On such a view, it is thus possible that recognizing and directly fulfilling a human right to health care may actually lead to a worse distribution of health than might otherwise be available. Public investments in health care may in practice not pay off as well as public investments elsewhere, precisely in terms of improved health.

Of course, the sheer magnitude of the resources available to promote health matters as well. And the magnitude of resources available to promote health, directly or indirectly, is of especially vital concern in cases of developing economies. In a developing country, the meaning of a human right to health care crucially depends upon whether the pool of available resources is confined largely to local wealth, or else includes substantial international transfers, of one sort or another, as well. As a leading contemporary philosopher has put the issue:

Is this right only a right to the standard of health that a person can attain with locally available and affordable treatment - however meagre that

103. MacDougall \& Trotter, supra note 98 , at 531.

104. See id.

105. See DANIELS, supra note 100; Filc, supra note 81; Gopal Sreenivasan, Health Care and Equality of Opportunity, 37 HASTINGS CTR. REP. 21, 27 (2007). For a more skeptical view of the social determinants argument, see Adina Preda \& Kristin Voigt, The Social Determinants of Health: Why Should We Care?, 15 Am J. Bioethics 25 (2015) (changes in wealth and income inequalities may be only poorly related to health outcomes).

106. Sreenivasan, supra note 105 , at 27 . We assume here that the incentive effects of both approaches are equal.

107. See id. (emphasis in the original). Sreenivasan recognizes as well that one's ill health, as in the case of a congenital disability, may affect one's opportunities to some degree independently of the society's accommodation thereof. 
me be? Or is it a right to the highest ${ }^{108}$ available globally ${ }^{109}-$ however expensive that may be? ${ }^{10}$

This question leads to the further question of the most morally persuasive approach to required public and private wealth transfers from relatively rich to poor on a global basis. ${ }^{111}$ It may well be that the moral demands of such wealth distribution are greater than is commonly acknowledged. ${ }^{112}$

The conversation regarding the redistributive requirements of a human right to health care should, clearly, continue. As a final suggestion for the moment, consider that some global health care problems must be addressed as we are now, with only our currently available resources, whether those resources are to be redistributed internationally or not. A current epidemic, for example, must be addressed largely in the present. That epidemic cannot be put on pause until we have generated additional resources to devote to prevention and cure.

But in other contexts, the tradeoffs between immediately addressing a health care problem full on, and instead only mitigating such current harms while also more rapidly building our collective resources for a more successful longer-term confrontation, may be dramatic. Generally, effective prevention and cure of major diseases becomes more feasible as the relevant societies make genuine progress economically, scientifically, and technologically. ${ }^{113}$ With continuing and compounding genuine economic growth and progress, what seems unrealistic in the moment may become readily manageable some limited number of years in the future. Medical care that is currently impossible, or at best heroically demanding, may become feasible, routine, relatively cheap, and uncontroversially deliverable.

More broadly, it is argued that:

The history of economic growth ${ }^{114}$ indicates that, with some

108. Or if not the "highest," at least some ambitious standard.

109. "Global" might conceivably refer to the attained, or attainable, standard of the single leading nation-state in this respect, or to something akin to a weighted or unweighted global average.

110. See Onora O'Neill, The Dark Side of Human Rights, 81 INT'L AfF. 427, 429 (2005).

111. From among a substantial literature, see generally Garrett Cullity, The Moral Demands of Affluence (2004); Tim Mulgan, The Demands of Consequentialism (2005); Peter Unger, Living High and Letting Die: Our Illusion of InNocence (1996); Richard J. Arneson, What Do We Owe to Distant Needy Strangers?, in Peter Singer Under Fire: The Moral ICONOClast Faces His Critics 267 (Jeffrey A. Schaler ed. 2009); Brad Hooker, The Demandingness Objection, in The Problem of Moral Demandingness ch 8, at 149 (T. Chappell ed. 2009). Classically and influentially, see Peter Singer, Famine, Affluence, and Morality, 1 PHIL. \& PuB. AfF. 229 (1971).

112. See the authorities cited supra note 111 .

113. These forms of genuine progress would reflect the broader Enlightenment project of gradually developing the individual and collective capacities of the human mind. See, e.g., JEANAntoine-Nicolas de Caritat, Marquis de Condorcet 1743-1794, Outlines of an Historical View of the Progress of the Human Mind 8, 237 (Ulan Press 2012) (1796).

114. This author seeks sustainable long-term growth, but only in a refined sense of "growth," 

TO HEALTH CARE

qualifications, growth alleviates misery, improves happiness and opportunity, and lengthens lives. Wealthier societies have better living standards, better medicines, and offer greater personal autonomy, greater fulfillment, and more sources of fun. ${ }^{15}$

Similarly, the point has been made that whether we welcome or object to the direct, indirect, or unintended results of technology, the idea of genuine technological progress itself seems to open the door to worthy projects. ${ }^{116}$ Whatever possibilities technological progress destroys, the idea of genuine progress refers ultimately refers to reducing mere waste, ${ }^{117}$ in the sense of gains in the efficiency with which the inputs needed to make goods and services are reduced. ${ }^{118}$ The formerly impossible then becomes possible, and even inexpensive, with the health results then depending partly on our willingness to redistribute the necessary resources to pay for such care to the less well off.

Of course, the choice to advance medical and other technologies may imply other, perhaps less appealing effects. ${ }^{119}$ New technologies of health care may require the abandonment of privacy. ${ }^{120}$ And if we emphasize unduly that tomorrow's economic, scientific, and technological progress will make health care more effective, less expensive, or less burdensome for the donors, we may then rationalize our unwillingness to redistribute resources to combat serious health crises today. ${ }^{121}$

Given the lack of consensus on this among other vital issues, the best collective choice at the moment would seem to involve continuing the ongoing

as distinct from mere GNP-based statistics.

115. Tyler Cowen, Stubborn Attachments 33 (2018); Cowen in turn cites, e.g., Steven Pinker, Enlightenment Now: The Case For Reason, Science, Humanism, and Progress ch. 6 (2018) (on health in particular); Benjamin M. Friedman, The Moral Consequences of ECONOMIC GROWTH ch. 4 (2006).

116. See Enrique Martinez-Garcia, Technological Progress is Key to Improving World Living Standards, 8 FED RES. BANK OF DALlas 4 (June, 2013) https:/www.dallasfed.org/research/ eclett/2013/el1304.cfm [https://perma.cc/G6DV-4N3U].

117. See id. at 1 .

118. See id.

119. For a classic discussion, see Jacques Ellul, The Technological Society (John Wilkinson trans., Vintage ed. 1984) (1964).

120. For current concerns, see, e.g., Brett Friedman \& Jennifer Romig, INSIGHT: Top 5 Privacy and Security Challenges for Adopters of Blockchain Technology in Health Care, BlOOMBerG L. (July 17, 2018), https://news.bloomberglaw.com/health-law-and-business/insighttop-5-privacy-and-security-challenges-for-adopters-of-blockchain-technology-in-health-care [https://perma.cc/A9UT-QQQT].

121. This question also implicates the problem of choosing an optimal social discount rate, which might include a rate of zero. For discussion, see CowEN, supra note 115, at ch. 4; Andrew Caplin \& John Leahy, The Social Discount Rate, (The Nat'1 Bureau of Econ. Res., Working Paper no. 7983, 2000), www.nber.org/papers/w7983 [https://perma.cc/QME5-KP5Y]. 
conversation.

\section{CONCLUSION}

Professor Kinney's largely natural law-based ${ }^{122}$ approach to an international human right to health care is a vital contribution to an ongoing conversation. As one interlocutor has concluded, those "who complain that we lack adequate philosophical foundations for the broad range of human rights recognized in international law are right. Developing such foundations, if possible, is a worthy task. .."123

One possible way to usefully continue Professor Kinney's conversational thread would be to try to take the edge off of the debates over philosophical justifications, ${ }^{124}$ alternative meanings of equality, ${ }^{125}$ and a variety of redistributional questions ${ }^{126}$ by emphasizing the appeal of what we might call a broadened sense of solidarity, community, and of (gender-neutral) fraternity. ${ }^{127}$ Perhaps some of the sharpest conflicts could be mitigated by attending to the role and value of these values. ${ }^{128}$

The thought here is that values such as solidarity are akin to contested notions of equality, but helpfully refer to much more concretely experienced relationships. There may well thus be contexts in which solidarity is of greater consequence, descriptively and normatively, than typically abstract understandings of equality and inequality. ${ }^{129}$ And part of the real value of equality

122. As elaborated in terms of the development and preservation of basic human functional capacities. See sources cited supra note 25; Norman Daniels, Just Health 316 (2008) (focusing in part on "protecting normal functioning").

123. DANIELS, supra note 122, at 314. Perhaps out of a sense of the likely futility of any such quest, these basic questions are set aside by philosophical pragmatists and others. See, e.g., Jonathan Wolff, The Human Right to Health 19-20 (2012) (“"[p]robably the right response ... is . . to acknowledge the limits of philosophical argument and allow the resulting disputes to be resolved through the development of democratic policies and legal doctrine"). See also Raz, supra note 55, at 14, 19 (on a "political" conception, "human rights need not be universal or foundational," or for that matter, "very important"). But see GRIFFIN, supra note 54, at 1. It is not obvious on what edifying and non-arbitrary grounds a "political" debate over human rights is then to be conducted. In the absence of any pursuit of genuinely better human right policies, the default motivator may be not a generous universalism, but perceived group interest.

124. See supra Section II.

125. See supra Section III.

126. See supra Section IV.

127. For a more elaborate treatment, see Wright, supra note 83.

128. For a useful conceptual exploration, see ANDREW MASON, COMMUNITY, SOLIDARITY AND Belonging: LeVels of Community and Their Normative SignificAnce (2000).

129. See R.H. Tawney, Equality 113 (Unwin ed. 1971) (1951). 
TO HEALTH CARE

may be in helping to generate relationships of friendship, solidarity, and community bonds. ${ }^{130}$ Solidarity may require, for example, a limitation on narrow self-interest, ${ }^{131}$ even to the point of meaningful self-sacrifice. ${ }^{132}$

130. See, e.g., Jean Hampton, Political Philosophy 154 (1997) (referring to Aristotle on equality and the value of community friendships); Elizabeth S. Anderson, What Is the Point of Equality?, 109 ETHICS 287, 288-89 (1999) (egalitarianism as properly "to create a community in which people stand in relations of equality to others").

131. See Andraes Eshete, Fraternity, 35 Rev. Metaphysics 27, 28 (1981); Lawrence Crocker, Equality, Solidarity, and Rawls' Maximin, 6 PHIL. \& PuB. Aff. 262, 263 (1977).

132. Consider the possibilities for reciprocal self-sacrifice by both providers and recipients of expensive end-of-life health care, given the emotional stakes and the alternative uses for such funding. 